\title{
The role of trade unions in fighting the effects of crisis
}

\begin{abstract}
This article examines briefly the response of trade unions to the financial crisis, from the perspective of the situation in Romania and the viewpoint of the Cartel Alfa trade union. The author explains that the country was already under pressure from the IMF and the EU arising from the impact of the country's attempt to join the Eurozone in 2014, but that a lack of capacity in the political arena is also presenting difficulties for the social situation, as is the hot topic of pensions reform. Cartel Alfa has called for measures to be taken in three directions which are aimed at helping to resolve the pressure, as well as for senior corporate executives in Romania to observe the principles of decent work. The union also wants to see agreements on the minimum wage observed, as a part of the essential process of achieving an effective social dialogue through which answers to the crisis may be established.
\end{abstract}

Keywords: economic crisis, trade unions, minimum wage, infrastructure investment, tax evasion, pensions reform, social dialogue

\section{Political situation}

The current social climate is rather tense in Romania as a result of the background of the efforts made by, and the restrictions imposed on the people in relation to the process of, European integration. These include the initial proposal for Romania to join the Eurozone in 2014. The crisis, then, represents extra pressure, causing ever more citizens to become poorer and more dissatisfied. To give just one example, the government claims that it is taking measures intended to help people out of the crisis, but people are seeing their income dwindle because of the ineffective enforcement of the law on unitary remuneration. At CNS Cartel Alfa, we have recently demanded the resignation of the Minister of Finance, as he is doing no more than proving that he is more interested in maintaining corruption and tax evasion than in adopting and promoting measures meant to benefit the citizens. This background is leading to a day-by-day deterioration in the social climate. Whatever their party, politicians are more interested in their own parties' internal affairs than in the welfare of citizens. When they do remember the latter, they tend suddenly to shift to an extremely populist and already-used discourse.

The government has proved to be totally irresponsible in the way it has tackled the crisis so far. In fact, public statements by both the Prime Minister and the President of the country indicate they may not do anything at all. We are actually waiting to see countries around us emerge from the crisis, looking hopefully at what developed countries are doing and adapting on the way some of the measures which seem to be applicable to Romanian realities. We must add that, in January-February 2009, under pres- 
sure from the social partners (trade unions and employers) and after an intense period of work, some 430 measures aimed at fighting the crisis in Romania were identified. The government of Romania took on only 27 of them and have enforced just three.

The major measures requested by the social partners, such as fighting tax evasion and irregularities in the economy and on the labour market have not been applied. The government has estimated that tax evasion in Romania amounts to $28 \%$, while the International Monetary Fund and the World Bank estimate that this figure is at least $40 \%$. If we had succeeded in cutting this down to $23 \%$, the country would not have been affected by the crisis.

Even if the results of 2009 were very bad, four months after the beginning of 2010 nothing has been done to mitigate it. Just a few minor things are being carried out, more as a result of pressure from the people in the street rather than as a result of a coherent policy (such as, for instance, in the case of technical unemployment, a measure which only started to be used again in February 2010, after 31000 jobs had been lost when this measure was not in use).

\section{Cartel Alfa proposals for change}

In this context, the proposals of the National Trade Union Confederation CNS Cartel Alfa are aimed at three major directions:

- increasing the minimum guaranteed wage, with a view to fighting evasion on the labour market and cutting the number of active people benefiting from social guarantees because of their low income (currently 1.7 million workers)

- making transparent investments in infrastructure (the Campina-Brasov work in association with French companies), or in products required by integrated enterprises (with 300 to 2500 suppliers in their supply chain) such as: Dacia cars; manufacturers of railway rolling stock (according to an agreement with the EU, we have to completely replace rolling stock by 2013; the tenders have been organised already but no order has been placed to that effect in the past two years)

- fighting tax evasion in sectors where it is easy to do so (VAT recovery, bakeries, etc.).

The legal framework must of course be improved, such as in the field of PPP (publicprivate partnerships). Investment in human resources, i.e. the continuous training or retraining of staff, is also required as a medium-term action. EU-supported programmes are particularly important and our confederation is acting as co-ordinator for two such programmes.

The main purpose of our trade union confederation is to put pressure on senior executives in Romania to take measures aimed at protecting decent work, including in the 'green' sector, in maintaining and creating jobs and in ensuring that the principles of social protection prevail. We are waging a permanent battle against reductions in income amongst various groups, some of which include the under-privileged. The government must understand that it is not a sufficient reaction to cut the income of various groups in order to mend other areas of economy which are suffering and ready to collapse if it does not, at the same time, support the revival of production and create new jobs. 
The Romanian press has mentioned that the government is preparing to lay off 100000 public servants. Ordinarily, this is not about the lay-off of 100000 employees paid within the state budget; it is about the elimination of 100000 jobs in public institutions encompassed within the state budget for which money has been allotted but which currently stand vacant. The real problem appears because the current government is not interested in a coherent social policy, but rather in providing openings for their political clients, as proven by countless pieces of legislation issued in 2009 to that effect, such as Emergency Ordinances 34 and 104 which have, however, been cancelled by the Constitutional Court. The government is therefore causing a process of the re-allocation of public employees to become a real process of the reduction in the number of public employees.

In addition, we are confronted with other major problems arising from agreements with the IMF and the EU. We refer here to the refusal by the government and employers to enforce the agreement on the minimum guaranteed paid wage. Consequently, the minimum wage has been frozen at 600 lei (approximately $€ 145$, which is only $30 \%$ of the gross average wage against the $34 \%$ stipulated for 2010). The agreement signed by the government, the employers and all the representative confederations of trade unions stipulates the gradual evolution of the relationship between the gross minimum wage and the gross average wage to $50 \%$ by 2015 . In order to support our viewpoints, we have started a series of activities which may go as far as the organisation of a general strike at the end of this summer, if this proves to be necessary.

Alongside the trade union members who are members of the Economic and Social Council, we believe that our use of the European social model, which emphasises social dialogue with a view to obtaining agreement, is an important means to help Greece and other countries in difficult situations.

\section{Pensions reform}

One of the big issues is that the costs of the crisis are being incurred by the citizens; however, this is of benefit to various interested parties: for example, the reform of the pensions system, which is one of the specific requirements of the IMF. The proposed reforms will see the amounts received as pensions decrease over twenty years - and retired people are already experiencing a dramatic decrease in their purchasing power.

At the same time, despite the deficit recorded in the past two years, i.e. since the second pillar of the pensions system became effective, it has become apparent that companies which are managing pensions funds have no liability for their management operations since they do not even guarantee that the value of the deposits will exceed the value of inflation for the period. However, following requests by the IMF and the European Union for investors to be able to recover their investment, contributions keep being transferred from the first pillar to the second.

We must add in addition that, under the combined blessing of the EU and the IMF, government action has resulted in the employer contribution to the first pillar decreasing, yet there has been no transfer from the state budget to the pensions funds, on behalf of the groups for which exemptions in the matter have been granted, so as to compensate for these exemptions. 
The reform of the first pillar of the pensions system is another hot topic. Even though we support the reform of the pensions system, we may not agree with the proposals submitted by the government, which are apparently supported by the IMF and the EU. These proposals actually aim at transforming pensions fund into profitable businesses for the sole use of the administrators of second pillar funds by eliminating the first pillar, despite its acknowledged role as a macroeconomic stabiliser, particularly during crisis situations.

\section{Conclusion}

Grant the priority to people, not to markets is a vital European principle. To provide just one example: any reform of pensions systems - this topic is a current one in Romania as well as in several EU member states - must rely both on protecting pensions and social security (and not on the measures imposed by governments who get frightened in the face of market pressures), as well as on using social dialogue and agreements. Another measure would be that the development of European economic governance be accepted by the setting up of new methods to collect funds such as, above all, a financial transactions tax, taxes on bonuses and the possibility of issuing Eurobonds. These measures must be accepted and adopted at a European scale, since it is evident that our economies and our European destinies are bound one to another.

The actions we have proposed are intended to develop gradually, with the aim of allowing social dialogue to be attained and for the social partners to be brought together.

I do not think that Romania will experience a similar situation to Greece; such an action (see also the case of France several years ago) calls on politicians all over Europe to react and pay attention to what may happen. We therefore hope that the representatives of the Romanian political class may grow more open to social dialogue, perhaps following 'a push from the outside', which will leads us to find the answers which are both proper and effective. 